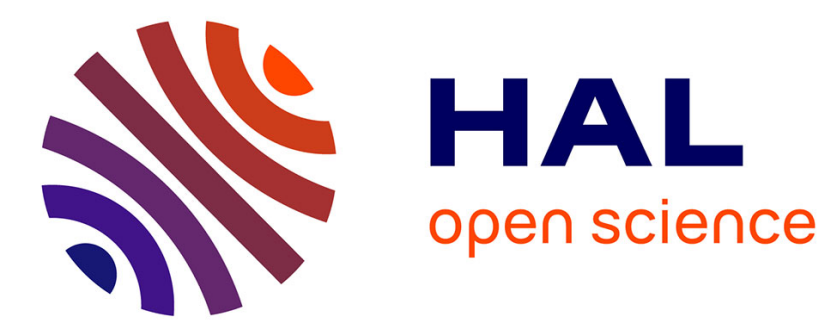

\title{
Temperature dependence of the shear modulus of soft tissues assessed by ultrasound
}

Emilie Sapin - de Brosses, Jean Luc Gennisson, Mathieu Pernot, Mathias

Fink, Tanter Mickael

\section{- To cite this version:}

Emilie Sapin - de Brosses, Jean Luc Gennisson, Mathieu Pernot, Mathias Fink, Tanter Mickael. Temperature dependence of the shear modulus of soft tissues assessed by ultrasound. 2009 IEEE International Ultrasonics Symposium, IEEE, Sep 2009, Rome, Italy. 10.1109/ULTSYM.2009.5441718 . hal-03275123

\section{HAL Id: hal-03275123 \\ https://hal.science/hal-03275123}

Submitted on 2 Jul 2021

HAL is a multi-disciplinary open access archive for the deposit and dissemination of scientific research documents, whether they are published or not. The documents may come from teaching and research institutions in France or abroad, or from public or private research centers.
L'archive ouverte pluridisciplinaire HAL, est destinée au dépôt et à la diffusion de documents scientifiques de niveau recherche, publiés ou non, émanant des établissements d'enseignement et de recherche français ou étrangers, des laboratoires publics ou privés. 


\title{
Temperature dependence of the shear modulus of soft tissues assessed by ultrasound
}

\author{
E Sapin, J-L Gennisson, M. Pernot, M. Fink, M. Tanter \\ Institut Langevin \\ ESPCI ParisTech, CNRS UMR 7587, INSERM ERL U979, Paris VII- Diderot University, Laboratoire Ondes et Acoustique \\ Paris, France. \\ Email: emilie.sapin@espci.fr
}

\begin{abstract}
Ultrasound-based techniques to monitor HIFU treatments, combining temperature and elasticity mapping, require better understanding of the thermal effects on soft tissues elasticity. Hence, the study aims to evaluate the temperature dependence of the shear modulus of bovine muscles.

Nine ex vivo samples of bovine muscle were slowly heated into a thermally-controlled saline bath. Thermocouples were used to assess temperatures into muscles. Local elasticity was assessed using Supersonic Shear Imaging. Samples were heated from $20^{\circ} \mathrm{C}$ to $70^{\circ} \mathrm{C}$ by steps of $10{ }^{\circ} \mathrm{C}$ and $20 \mathrm{~min}$ long and cooled back at room temperature. Elasticity assessment was achieved every minute along the muscular fibres.

The shear modulus decreased linearly with increasing temperature up to $44^{\circ} \mathrm{C}$, with a change in slope around $37^{\circ} \mathrm{C}$. Then, it exponentially decreased from $44^{\circ} \mathrm{C}$ to $56^{\circ} \mathrm{C}$. Finally, it exponentially increased for higher temperatures.

The thermal-induced changes in the shear modulus of ex vivo bovine muscles using ultrasound are consistent with theorical changes of myosin and collagen microstructure.

Given the high sensitivity of the ultrasound-based technique to the behaviour of both myofibrilar proteins and collagen on heating, this study gives promising prospects for the use of a fullultrasound-based technique to monitor thermal effects on tissues.
\end{abstract}

Key words - Muscle, Elasticity, Thermal effect, Supersonic shear imaging.

\section{INTRODUCTION}

A $\mathrm{n}$ increasing interest is given to high intensity focused ultrasound (HIFU) for thermal ablation of tumors. However, there are currently few methods for real-time monitoring of the therapy. Direct assessment of the temperature has been proposed using magnetic resonance imaging (MRI) with a good accuracy but the clinical use of MRI is limited by its cost, its accessibility and its temporal resolution. On the other hand, ultrasonic methods have been proven to detect in vitro HIFU lesions [1-4] but still have to be improved for in vivo clinical uses.

Another approach consists in the assessment of the changes in lesion stiffness with temperature. Supersonic Shear Imaging
(SSI) is an ultrasound-based technique that provides quantitative shear modulus mapping of soft media. Acoustic radiation force is remotely induced in tissue using a short $(\sim 100 \mu \mathrm{s})$ burst of focused ultrasound to create a low frequency shear wave in the medium. Then, images of the propagation of the resulting transient shear waves are made at ultrahigh frame rate (up to 10,000 images/s), from which the elasticity map is recovered by solving a local inverse problem $[5,6]$. This method could be clinically relevant to create a fully ultrasonic-based device monitoring HIFU treatments. However, there is a need to better understand the temperature dependence of the elasticity of healthy and malignant tissues.

The behaviour of myofibrils, sarcoplasmic proteins and collagen fibres on heating has been well studied in the field of food technology [7], but there is currently no globally accepted thermo-mechanical model that describes the changes of the shear modulus of a whole tissue with temperature because of the complex interactions between fibres $[8,9]$. The most complete study was conducted by $\mathrm{Wu}$ et al. who had assessed a decrease of the shear modulus of bovine muscles with increasing temperature between $20^{\circ} \mathrm{C}$ and $60{ }^{\circ} \mathrm{C}$ and then an increase above $60{ }^{\circ} \mathrm{C}$ corresponding to the threshold of collagen denaturation [10]. These patterns have been observed using magnetic resonance elastography (MRE), which has the limitations and inconvenient of MRI. Furthermore, the frame rate of elasticity maps provided by MRE limits the applicability of this approach.

Hence, the aim of the study is to quantify the temperature dependence of the shear modulus of bovine muscle tissue. A specific attention was paid to test the reproducibility of patterns on many samples in order to take into account the inter-individual variability.

\section{MATERIAL AND METHODS}

\section{A. Specimens}

Nine samples extracted from 9 bovine muscles (rump roast beef from butcher shop) were considered. Information about the preservation of the meat was not accessible. Samples were pseudo-parallelepipeds whose dimensions ranged between 
$8 \times 4 \times 2$ and $10 \times 9 \times 5 \mathrm{~cm}^{3}$ (length, width and depth).

\section{B. Temperature assessment}

The samples were slowly warmed up and cooled down into a thermally-controlled saline bath (thermal unit: Ministat 125, Hueber - Fig.1). The saline bath was heated from $20{ }^{\circ} \mathrm{C}$ to $70{ }^{\circ} \mathrm{C}$ by steps of $10^{\circ} \mathrm{C}$ high and $20 \mathrm{~min}$ long and then cooled back at room temperature following the same steps (Fig2).

Temperatures were assessed every minute using three thermocouples (type $\mathrm{J}$, accuracy $=1.5{ }^{\circ} \mathrm{C}$ ), connected to a multichannel acquisition board (Sensoray Model 7409TB). One thermocouple was placed into the bath and the two others were into the bovine samples at two distant points (differences lower than $2{ }^{\circ} \mathrm{C}$ ). In the following, the temperature within the sample is the average of the two measures.

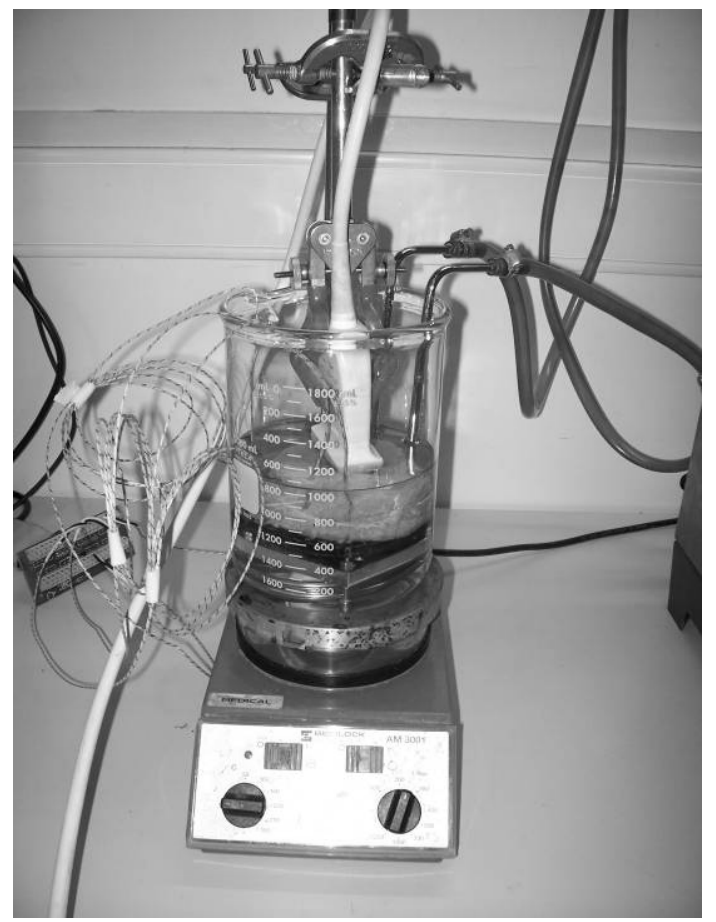

Fig 1. Experimental set up: muscles are warmed up in a thermally controlled saline bath. Temperatures are assessed every minutes using thermocouples. Elasticity map are acquired every minutes using a conventional probe driven by an ultrasound research system (V1, Supersonic Imagine, Aix-en-Provence, France).

\section{Supersonic Shear Imaging sequence}

Local elasticity was assessed using the Supersonic Shear Imaging technique. The elasticity mapping was achieved every minute in a plane parallel to the main direction of the muscular fibres (longitudinal shear modulus). A region of interest (ROI) was manually chosen both to have a ROI as large as possible and to avoid boundary artefacts. The mean shear modulus of the sample $(\mu)$ was computed as the median of the local values into the ROI.

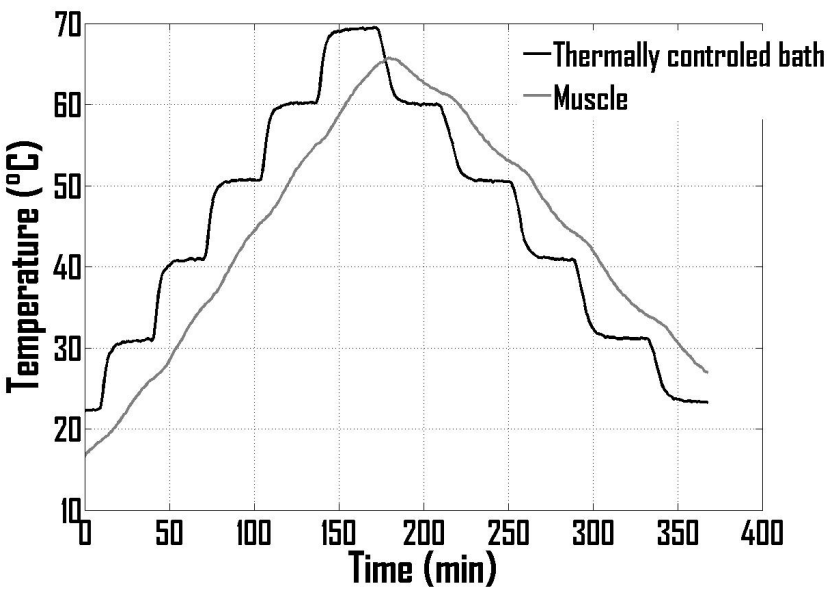

Fig 2. Evolution of the temperature in the thermally controlled saline bath and into the muscle during the experiment.

\section{RESULTS}

\section{A. Descriptive statistics}

The mean initial longitudinal shear modulus over the nine samples was equal to $77 \pm 37 \mathrm{kPa}$. According to the variation of the initial shear modulus, normalized values are used below.

\section{B. Evolution of the shear modulus with temperature}

The changes of the normalized shear modulus (shear modulus / initial shear modulus) are divided in four phases (Fig.3). First, it linearly decreases up to about $44{ }^{\circ} \mathrm{C}$ with a change in slope at $37^{\circ} \mathrm{C}$ (Phase 1 and 2: mean slope equal to - $2.5 \% \pm 0.8 \%$ per degree and $-1.5 \% \pm 0.9 \%$ per degree respectively). Then it exponentially decreases up to $56{ }^{\circ} \mathrm{C}$ (phase 3). Finally, it exponentially increases above $56^{\circ} \mathrm{C}$.

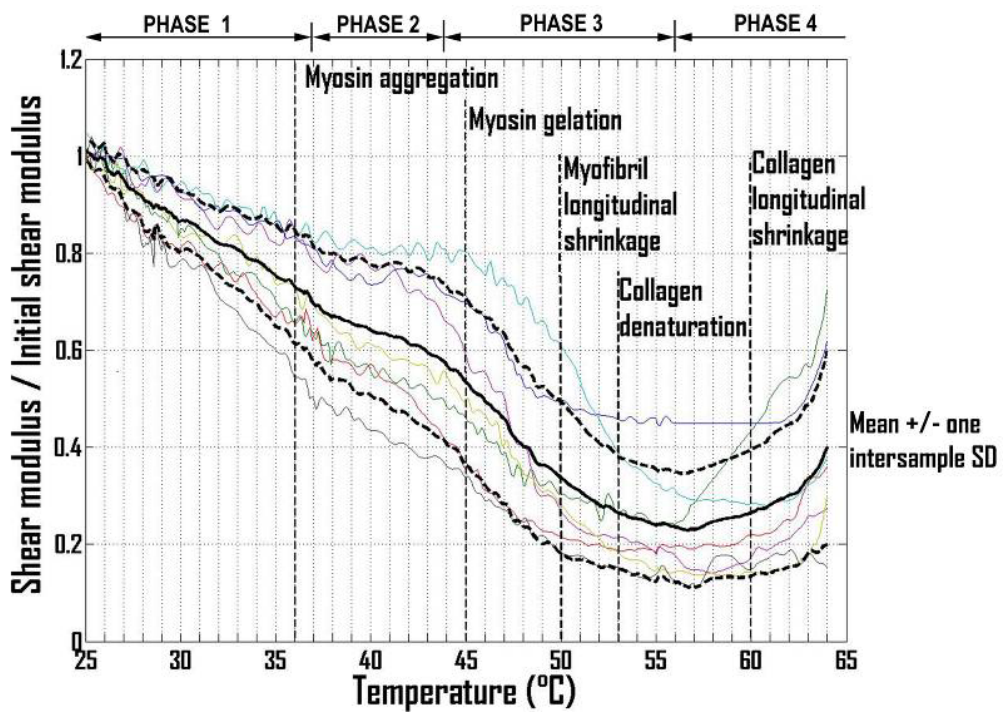

Fig.3. Evolution of the normalized longitudinal shear modulus (along muscular fibres) with temperature for nine muscles: comparison between the average behaviour (average curve \pm 2 standard deviation) and the theorical thresholds of protein denauration [7]. 


\section{DISCUSSION}

In the context of thermal ablation of tumors using HIFU devices, the prediction of in vivo heat-induced changes remains problematic. Hence, the present study was aimed at quantifying the variations of the shear modulus of bovine muscle tissues during controlled hyperthermia using the SSI ultrasonic method.

The shear moduli assessed using SSI (between $17 \mathrm{kPa}$ and $128 \mathrm{kPa}$ ) were slightly higher than values reported using magnetic resonance elastography (between 20 and $70 \mathrm{kPa}$ ) $[10,11]$. It is probably due to the variability of the mechanical properties between different skeletal muscles due to the different anatomical location, the muscular fibres organization or the fat infiltration. According to the shear modulus variability, normalized values were used in this study (shear modulus divided by the initial value) to allow comparisons between samples.

The thermal changes in elasticity could be divided in four phases during heating. Firstly, the normalized shear modulus linearly decreased up to $44^{\circ} \mathrm{C}$, corresponding to the proteins unfolding process (myosin and collagen) [8-10, 12, 13]. A change in slope is observed at about $37^{\circ} \mathrm{C}$, corresponding to the formation of myosin-myosin complexes (myosin aggregation) for myofibrils in solution [7]. Then, the normalized shear modulus exponentially decreased between $44{ }^{\circ} \mathrm{C}$ and $56{ }^{\circ} \mathrm{C}$. This change of behaviour could be explained by the gelation of myosin that tends to soften the medium [7]. Above $56{ }^{\circ} \mathrm{C}$, the normalized shear modulus exponentially increased with increasing temperature, due to the collagen denaturation and the longitudinal shrinkage of myofibrils and collagen $[7-10,12,13]$. These changes are globally consistent with previous studies $[10,11]$. In details, the model is however different from $\mathrm{Wu}$ et al 's previous observations [10]. Indeed, they assessed linear evolutions of the shear modulus with temperature. Up to $60{ }^{\circ} \mathrm{C}$, the shear modulus decreased with a slope equal to the present one $\left(-1.4 \mathrm{kPa} /{ }^{\circ} \mathrm{C}\right.$ with an initial shear modulus equal to $70 \mathrm{kPa})$, and then it increases with temperature above $60{ }^{\circ} \mathrm{C}$ (with a slope equal to $5.9 \mathrm{kPa} /{ }^{\circ} \mathrm{C}$ ). The difference may be due to the different shear wave frequency and bandwidth that were used. Besides, it may be due to the different rate of assessment: one assessment per minute in the present study (smaller rates could be chosen with the SSI device) vs one assessment about every 5 minutes in Wu's study. Thus, the ultrasonic technique seems to be very sensitive to small changes of elasticity due to microscopic changes of proteins structure.

The main limitation of the study is the restriction of the thermal estimations to a very local area as the thermometry is performed at only two point-like locations provided by the thermocouples, whereas elasticity is mapped over a large region of interest. Consequently, temperature spatial heterogeneities are not taken into account. Current work is in progress to provide thermal maps with ultrasound, for one-toone comparison with elasticity maps.

\section{CONCLUSION}

To conclude, the study provides significant improvement in the prediction of the complex thermal effects on muscle elasticity. Especially, the ultrasonic device seems to be sensitive to the denaturation of both myosin in myofibrils and collagen in connective tissues. Even if these patterns should be confirmed with experimental conditions closer to the clinical HIFU treatments (local thermal effects, in vivo conditions, human tissues), this study gives promising prospects for the prediction and the monitoring of thermal effects on tissues, using a full-ultrasound-based technique.

\section{REFERENCES}

[1] Maass-Moreno R, Damianou CA. 1996. Noninvasive temperature estimation in tissue via ultrasound echo-shifts. Part I. Analytical model. The Journal of the Acoustical Society of America 100 (4), 2514-2521.

[2] Maass-Moreno R, Damianou CA, Sanghvi NT. 1996. Noninvasive temperature estimation in tissue via ultrasound echo-shifts. Part II. In vitro study. The Journal of the Acoustical Society of America 100 (4), 2522-2530.

[3] Miller NR, Bamber JC, Meaney PM. 2002. Fundamental limitations of noninvasive temperature imaging by means of ultrasound echo strain estimation. Ultrasound in Medicine \& Biology 28 (10), 1319.

[4] Pernot M, Tanter M, Bercoff J, Waters KR, Fink M. 2004. Temperature Estimation Using Ultrasonic Spatial Compound Imaging. IEEE transactions on ultrasonics, ferroelectrics, and frequency control 51 (5), 606-615.

[5] Bercoff J, Pernot M, Tanter M, Fink M. 2004. Monitoring thermallyinduced lesions with supersonic shear imaging. Ultrasonic Imaging 26 (2), 71-84.

[6] Bercoff J, Tanter M, Fink M. 2004. Supersonic Shear Imaging: A New Technique for Soft Tissue Elasticity Mapping. IEEE transactions on ultrasonics, ferroelectrics, and frequency control 51 (4), 396-409.

[7] Tornberg E. 2005. Effects of heat on meat proteins - implications on structure and quality of meat products. Meat Science 70 493-508.

[8] Lepetit J, Grajales A, Favier R. 2000. Modelling the effect of sarcomere length on collagen thermal shortening in cooked meat: consequence on meat toughness. Meat Science 54 (3), 239.

[9] Lepetit J. 2007. A theorical approach of the relationships between collagen content, collagen cross-links and meat tenderness. Meat Science 76 147-159.

[10] Wu T, Felmlee J, Greenleaf J, Riederer S, Ehman R. 2001. Assessment of thermal tissue ablation with MR elastography. Magnetic Resonance in Medicine 45 (1), 80-87.

[11] Kruse SA, Smith JA, Lawrence AJ, Dresner MA, Manduca A, Greenleaf $\mathrm{J}$, et al. 2000. Tissue characterization using magnetic resonance elastography: preliminary results. Physics in Medicine and Biology (6), 1579 .

[12] Wright NT, Humphrey JD. 2002. Denaturation Of Collagen Via Heating: An Irreversible Rate Process. Annual Review of Biomedical Engineering 4 (1), 109-128.

[13] Lepetit J. 2008. Collagen contribution to meat toughness: theorical aspects. Meat Science 80 960-967 the biography. 